\title{
Tinjauan Hukum Terhadap Pembatalan Sertifikat Hak Pakai Tanah Sebagai Aset Pemerintah Pada Badan Pertanahan Nasional Kota Samarinda \\ (Di Tinjau Dari Peraturan Menteri Agraria/Kepala Badan Pertanahan Nasional \\ Nomor 9 Tahun 1999 Tentang Tata Cara Pemberian Dan Pembatalan \\ Hak Atas Tanah Negara Dan Hak Pengelolaan)
}

\author{
Angga Septika Chandra dan Hudali Mukti \\ hudalimuktiuwgm@gmail.com \\ Alumni dan Dosen Fakultas Hukum Universitas Widya Gama Mahakam Samarinda
}

\begin{abstract}
ABSTRAK
Pembatalan sertifikat hak pakai tanah pada tanah negara sebagai bagian dari aset pemerintah menimbulkan polemik terkait dapatkah sertifikat hak pakai tanah pada tanah negara yang telah menjadi nilai aset pemerintah dibatalkan oleh Badan Pertanahan Nasional atau tidak dapat dibatalkan karena telah menjadi aset tetap pemerintah. Selain itu bila dapat dibatalkan bagaimana dengan status tanah akibat pembatalan sertifikat hak pakai tanah diatas tanah negara sedangkan tanah negara tersebut telah tercatat sebagai aset pemerintah. Dalam ruang lingkup daerah Pemerintah Kota Samarinda juga tidak terlepas dari polemik tersebut. Banyaknya tanah negara yang tercatat sebagai aset Pemerintah Kota Samarinda yang diakui hanya sebagian saja yang bersertifikat hak pakai tanah sedangkan sebagian lagi masih belum di sertifikasikan namun telah diinventarisasi sebagai aset Pemerintah Kota Samarinda. Hal tersebut mendorong Badan Pertanahan Nasional yang diwakili oleh Badan Pertanahan Nasional Kota Samarinda untuk lebih aktif turut serta dalam menyelesaikan polemik terkait prosedur pembatalan sertifikat hak pakai atas tanah sebagai satu-satunya alat penegak hukum agraria nasional dengan melaksanakan sesuai ketentuan peraturan perundang-undangan yang berlaku salah satunya ialah Peraturan Menteri Negeri Agraria/Kepala Badan Pertanahan Nasional Nomor 9 Tahun 1999 Tentang Tata Cara Pemberian Dan Pembatalan Hak Atas Tanah Negara Dan Hak Pengelolaan.
\end{abstract}

Kata Kunci : Pembatalan Sertifikat Hak Pakai Tanah, Aset Pemerintah, dan Badan Pertanahan Nasional Kota Samarinda

\section{ABSTRACT}

Cancellation of certificate of land usage rights on State land as part of the Government's assets give rise to polemics associated certificate can land usage rights on State land that has become the Government's asset value was cancelled by the national land Agency or cannot be cancelled because it has been the Government's fixed assets. In addition when be cancelled how by the status of the land due to the cancellation of the certificate of land usage rights above State land while the State land has been recorded as assets of the Government. Within the scope of the area of Government of the city of Samarinda is also inseparable from the polemic. The large number of State land is recorded as an asset the City Government recognized only part of America that is certified to land usage rights while some were still not in sertification but has inventoried as an asset the City Government Samarinda. It encourages the national land Agency represented by the national land agency of the city of Samara to more actively participate in resolving the related certificate revocation procedures polemic usage rights over the land as the only means of national agrarian law enforcement by carrying out in accordance with the applicable legislation, one of which is the regulation of the Minister of Agrarian Affairs/Head of the national land Agency 9 year 1999 Number Of procedures for Granting And The Cancellation Of The Country's Land Rights And Rights Management.

Key Word: Cancellation of certificate of Land usage rights, Government Assets, the national land Agency and the city of Samarinda. 


\section{PENDAHULUAN}

Tanah merupakan kebutuhan hidup manusia yang sangat mendasar. Manusia hidup dalam melakukan aktivitas diatas tanah sehingga setiap saat manusia selalu berhubungan dengan tanah, dapat dikatakan hampir semua kegiatan hidup manusia baik secara langsung maupun tidak langsung selalu memerlukan tanah. Oleh karena itu demi kesehjateraan rakyat tanah lebih jauh diatur oleh hukum.

Tanah dalam arti hukum memiliki peranan yang sangat penting dalam kehidupan manusia karena dapat menentukan keberadaan dan kelangsungan hubungan dan perbuatan hukum, baik dari segi individu maupun dampak bagi orang lain. Untuk mencegah masalah tanah tidak sampai menimbulkan konflik kepentingan dalam masyarakat, diperlukan pengaturan, penguasaan dan penggunaan tanah atau dengan kata lain disebut dengan hukum tanah. ${ }^{1}$ Berdasarkan hal tersebut, negara berkewajiban mewujudkan kesejahteraan masyarakat melalui kepastian hukum dengan menciptakan payung hukum mengenai tanah itu sendiri. Dalam hal ini maka diundangkanlah Undang-undang Nomor 5 Tahun 1960 Tentang Peraturan Dasar Pokok-Pokok Agraria. Dengan diundangkannya UUPA, berarti sejak saat itu Indonesia telah memiliki Hukum Agraria Nasional yang merupakan warisan kemerdekaan setelah pemerintahan kolonial Belanda $^{2}$

Hal ini sesuai dengan amanat konstitusi undang- undang dasar 1945 yang ada pada pasal 33 ayat 3 Undang-Undang Dasar Republik Indonesia yang telah menggariskan kebijakan dasar mengenai penguasaan dan penggunaan sumbersumber daya alam yang ada, dengan katakata. "Bumi dan air dan kekayaan alam yang terkandung didalamnya dikuasai oleh Negara, dan dipergunakan untuk sebesarbesar kemakmuran rakyat." Dan di pertegas

1 K. Wantijk Saleh, 1982, Hak Anda Atas Tanah, Jakarta, Ghalia Indonesia, Hal. 7.

${ }^{2}$ Sudjito, 1987, Prona Pensertifikatan Tanah Secara Massal dan Penyelesaian Sengketa Tanah yang bersifat Strategis, Yogyakarta, Liberty, Hal. 1. kembali tentang pengertian tanah dalam Pasal 1 ayat 4 Undang-Undang Nomor 5 Tahun 1960 Tentang Peraturan Dasar Pokok-Pokok Agraria menjelaskan dalam pengertian Bumi selain permukaan bumi, termasuk pula tubuh bumi, dibawahnya serta yang berada di bawah air.

Berdasarkan hal tersebut, maka jelaslah Negara menguasai untuk melindungi kepentingan rakyat dalam menguasai tanah yang dipergunakan sebaik-baiknya oleh rakyat. Dengan kata lain, hak menguasai tanah dilindungi oleh hukum dengan memberikan kewenangan kepada pemegang hak untuk menguasai tanah secara fisik. Hal ini diatur lebih lanjut dalam Undang-Undang Nomor 5 Tahun 1960 Tentang Peraturan Dasar PokokPokok Agraria diatur dan ditetapkan tata jenjang atau hierarki hak-hak penguasaan atas tanah dalam Hukum Tanah Nasional, yaitu :

1. Hak Bangsa Indonesia yang disebut dalam Pasal 1, sebagai hak penguasaan atas tanah yang tertinggi, beraspek perdata dan publik.

2. Hak Menguasai dari Negara yang disebut dalam Pasal 2, beraspek publik.

3. Hak Ulayat Masyarakat Hukum Adat yang disebut dalam Pasal 3, beraspek perdata dan publik.

4. Hak-hak perorangan/individual, semuanya beraspek perdata terdiri atas:

a. Hak-hak atas Tanah sebagai hakhak individual yang semuanya secara langsung ataupun tidak langsung bersumber pada Hak Bangsa, yang disebut dalam Pasal 16 dan 53.

b. Wakaf, yaitu Hak Milik yang sudah diwakafkan dalam Pasal 49.

c. Hak Jaminan atas Tanah yang disebut "Hak Tanggungan" dalam Pasal 25, 33, 39, dan 51. 
Berbicara mengenai penguasaan negara terhadap tanah maka dapat juga di artikan bahwa negara dapat memberikan tanah kepada seseorang atau badan hukum dengan suatu hak, misalnya hak milik, hak pakai, hak guna usaha, hak guna bangunan, dll yang telah di atur dalam Undang-undang Nomor 5 Tahun 1960 Tentang Peraturan Dasar Pokok-Pokok Agraria.

Selain itu, menurut Muhammad Bakri dalam bukunya yang berjudul Hak Menguasai Tanah Oleh Negara menyatakan bahwa Penguasaan tanah oleh Negara dibedakan atas penguasaannya secara penuh yaitu terhadap tanah-tanah yang tidak dipunyai dengan suatu hak oleh suatu obyek hukum, dan penguasaan tanah secara terbatas / tidak penuh yaitu terhadap tanah-tanah yang sudah dipunyai dengan suatu hak oleh suatu subyek hukum (tanah hak) atau tanah yang dikuasai tidak langsung oleh Negara. ${ }^{3}$ Menurut, John Salindeho dalam bukunya yang berjudul Masalah Tanah dalam Pembangunan bahwa tanah negara adalah sama dengan tanah yang langsung dikuasai oleh Negara. Jadi " tanah negara adalah semua tanah yang " belum dihaki" dengan hak- hak perorangan oleh UUPA. Tanah yang sudah dim iliki oleh suatu badan/instansi Pemerintah, adalah tanah negara pula, tetapi sudah dib erikan dan melekat hak atas sesuai ketentuan yang berlaku (Hak Pakai dan Hak Pengelolaan)". ${ }^{4}$

Dengan kata lain, penguasaan tanah oleh negara mencakup seluruh tanah yang berada di wilayah negara republik Indonesia yang tidak memiliki status hak atas tanah yang lebih di kenal sebagai tanah negara.

Di era modernisasi sekarang, konsep tanah negara menimbulkan persepsi negatif terhadap negara. Untuk diketahui bahwa penguasaan tanah negara diwakili oleh pemerintah baik pemerintah pusat maupun pemerintah daerah, sehingga tanah-tanah

${ }^{3}$ Muhammad Bakri, 2007, Hak Menguasai Tanah Oleh Negara, Yogyakarta, Citra Media, hal. 37

4 John Salindeho, 1993, Masalah Tanah Dalam Pembangunan, Jakarta, Sinar Grafika, hal. 171. tersebut yang berstatus tanah negara dapat diakui sebagai aset tetap daerah. Hal ini sesuai dengan adanya Peraturan Pemerintah Nomor 8 Tahun 1953 tentang Penguasaan Tanah-Tanah Negara, bahwa tanah negara dikuasai oleh pemerintah berdasarkan surat keputusan pemberian hak yang diterbitkan oleh Menteri Dalam Negeri yang sekarang diterbitkan oleh Kepala Badan Pertanahan Nasional.

Menurut Maria S.W. Soemardjono dalam bukunya yang berjudul Kebijakan Pertanahan; Antara Regulasi dan Implementasi menyatakan bahwa tanah ini merupakan tanah negara karena berdasarkan Staatsblaad Tahun 1911 Nomor 110 tentang Penguasaan BendaBenda Tidak Bergerak, Gedung-Gedung dan Lain-Lain Bangunan Milik Negara juncto Peraturan Pemerintah Nomor 8 Tahun 1953 tentang Penguasaan TanahTanah Negara, instansi pemerintah yang telah menguasai tanah sejak zaman Pemerintahan Hindia Belanda sampai berlakunya Peraturan Pemerintah Nomor 8 tahun 1953 maka tanah tersebut berstatus dalam penguasaan (in beheer) instansi pemerintah yang bersangkutan. ${ }^{5}$

Berkaitan dengan hal tersebut, maksud dari penulis terhadap persepsi negatif masyarakat mengenai konsep tanah negara ini, adalah timbulnya kesewenangwenangan negara terhadap penguasaan tanah negara yang diwakili oleh pemerintah daerah dalam lingkup penelitian ini ialah Pemerintah Kota Samarinda dimana tanah negara yang telah tercatat sebagai aset pemerintah tersebut seolah-olah menjadi milik Pemerintah dalam lingkup penelitian ini ialah Pemerintah Kota Samarinda. Artinya, peruntukkann dan penggunaan tanah negara yang menjadi aset pemerintah dilakukan semena-mena seolah-olah Pemerintah dalam lingkup penelitian ini ialah Pemerintah Kota Samarinda memiliki alas hak milik diatas tanah negara tersebut, padahal batasan alas hak tanah yang diberikan oleh negara hanya sebatas alas

${ }^{5}$ Maria S.W. Soemardjono, 2006. Kebijakan Pertanahan : Antara Regulasi dan Implementasi. Jakarta, Kompas. Hal. 63. 
hak pakai, sehingga yang merasakan dampaknya adalah masyarakat itu sendiri, padahal bedasarkan amanat Pasal 33 ayat (3) UUD 1945 mengenai bumi, air, dan kekayaan alam yang terkandung di dalamnya dikuasai oleh negara dan dipergunakan untuk sebesar-besarnya kemakmuran rakyat, penggunaan tanah negara diperuntukkan untuk kepentingan rakyat. Hal ini menimbulkan ironi terhadap realita penguasaan tanah oleh negara yang dalam hal ini pemerintah daerah dianggap merupakan perwakilan negara, padahal penguasaan tanah yang digunakan oleh pemerintah daerah dalam lingkup penelitian ini ialah Pemerintah Kota Samarinda hanya sebatas hak pakai, sehingga tentu dapat dibatalkan berdasarkan ketentuan aturan Peraturan Menteri Negara Agraria/Kepala Badan Pertanahan Nasional Nomor 9 Tahun 1999 Tentang Tata Cara Pemberian Dan Pembatalan Hak Atas Tanah Negara Dan Hak Pengelolaan. Hanya saja yang harus diteliti kembali untuk meluruskan persepsi negatif apakah sertifikat hak pakai yang telah tercatat sebagai aset pemerintah dalam lingkup penelitian ini ialah Pemerintah Kota Samarinda dapat dibatalkan berdasarkan prosedur pembatalan sertifikat hak pakai tanah yang ada pada ketentuan aturan Peraturan Menteri Negara Agraria/Kepala Badan Pertanahan Nasional Nomor 9 Tahun 1999 Tentang Tata Cara Pemberian Dan Pembatalan Hak Atas Tanah Negara Dan Hak Pengelolaan. Berkaitan dengan hal tersebut, maka dalam hal ini posisi kedudukan Badan Pertanahan Nasional tentu memiliki peranan penting sebagai alat penegak hukum agraria satusatunya khususnya dalam mewujudkan hak menguasai tanah oleh negara. Maksud dari peranan penting, terlihat pada peran Badan Pertanahan Nasional sebagai pelaksana pembatalan sertifikat hak pakai tanah diatas atas tanah negara sesuai ketentuan Peraturan Menteri Negara Agraria/Kepala Badan Pertanahan Nasional Nomor 9 Tahun 1999 Tentang Tata Cara Pemberian Dan Pembatalan Hak Atas Tanah Negara Dan Hak Pengelolaan. Hanya saja, kendala yang timbul adalah ketika Badan Pertanahan Nasional diberikan wewenang hanya sebatas menunggu untuk menyelesaikan bukan sebagai mediator, atau pengambil keputusan dalam penyelesaian konflik antara masyarakat dengan pemerintah terkait pembatalan sertifikat pinjam pakai tanah sebagai aset pemerintah.

\section{Perumusan Masalah}

Adapun Permasalahan dalam penelitian ini adalah :

1. Bagaimana proses pembatalan status tanah terhadap sertifikat hak pakai tanah sebagai aset pemerintah pada Badan Pertanahan Nasional Kota Samarinda?

2. Apa saja kendala yang dihadapi Badan Pertanahan Nasional Kota Samarinda dalam proses pembatalan sertifikat hak pakai tanah sebagai aset pemerintah Kota Samarinda ?

\section{Tujuan dan Manfaat Penelitian}

dapun penelitian bertujuan ntuk mengetahui dan memahami proses pembatalan status tanah terhadap sertifikat hak pakai tanah sebagai aset pemerintah pada Badan Pertanahan Nasional Kota Samarinda. Dan untuk memberikan gambaran tentang kendala yang dihadapi Badan Pertanahan Nasional Kota Samarinda dalam proses pembatalan sertifikat hak pakai tanah sebagai aset pemerintah Kota Samarinda.

Adapun kegunaan dilaksanakannya penelitian hukum ini adalah Untuk memberikan sumbangan pengetahuan dalam menyelesaikan sengketa pertanahan guna memberikan gambaran tentang tinjauan hukum terhadap pembatalan sertifikat hak pakai tanah sebagai aset pemerintah di Badan Pertanahan Nasional Kota Samarinda, dan untuk mampu memberikan jawaban terhadap permasalahan yang di teliti mengenai tinjauan hukum terhadap pembatalan sertifikaat hak pakai tanah sebagai aset pemerintah di Badan Pertanahan Nasional Kota Samarinda.

\section{METODE PENELITIAN}

Jenis penelitian dalam penelitian ini adalah yuridis empiris yang dengan kata lain adalah jenis penelitian hukum 
sosiologis dan dapat disebut pula dengan penelitian lapangan, yaitu mengkaji ketentuan hukum yang berlaku serta apa yang terjadi dalam kenyataannya di masyarakat. Atau dengan kata lain yaitu suatu penelitian yang dilakukan terhadap keadaan sebenarnya atau keadaan nyata yang terjadi di masyarakat dengan maksud untuk mengetahui dan menemukan faktafakta dan data yang dibutuhkan, setelah data yang dibutuhkan terkumpul kemudian menuju kepada identifikasi masalah yang pada akhirnya menuju pada penyelesaian masalah. $^{6}$

Sumber data yang digunakan di dalam penelitian ini diambil dari data primer dan data sekunder.

a. Data primer adalah data yang diperoleh secara langsung dari sumber pertama yang terkait dengan permasalahan yang akan dibahas. ${ }^{7}$ Sumber data diperoleh dari lapangan secara langsung dengan wawancara di Kantor Pertanahan Samarinda.

b. Data sekunder adalah data-data yang diperoleh dari buku-buku sebagai data pelengkap sumber data primer. Data sekunder mencakup dokumendokumen, buku, hasil penelitian yang berwujud laporan, dan seterusnya. ${ }^{8}$ Adapun buku yang menjadi sumber data sekunder adalah buku buku tentang pembatalan sertifikat pinjam pakai tanah sebagai aset pemerintah serta peraturan perundang-undangan terkait pembatalan sertifikat pinjam pakai tanah sebagai aset pemerintah, diantaranya:

1. Undang-Undang Dasar 1945 (UUD) Amandemen IV

2. Undang-Undang Nomor 5 Tahun 1960 tentang Undang-Undang Pokok Agraria

6 Bambang Waluyo, 2002, Penelitian Hukum Dalam Praktek, Jakarta, Sinar Grafika, hal.15-16

7 Amiruddin, 2006, Pengantar Metode Penelitian Hukum. Jakarta: PT Raja Grafindo Persada:.hal.30.

${ }^{8}$ Ibid.
3. Peraturan Pemerintah Nomor 40 Tahun 1996 tentang Hak Guna Usaha, Hak Guna Bangunan Dan Hak Pakai Atas Tanah

4. Peraturan Menteri Negara Agraria/Kepala Badan Pertanahan Nasional Nomor 9 tahun 1999 tentang Tata Cara Pemberian Dan Pembatalan Hak Atas Tanah Negara Dan Hak Pengelolaan

5. Peraturan Menteri Negara Agraria dan Tata Ruang/Kepala Badan Pertanahan Nasional Republik Indonesia Nomor 11 tahun 2016 tentang Penyelesaian Kasus Pertanahan

6. Keputusan Menteri Negara Agraria/ Kepala Badan Pertanahan Nasional Nomor 6 Tahun 1998 Tentang Pemberian Hak Milik Atas Tanah Untuk Rumah Tinggal

\section{Metode dan Teknik Pengumpulan Data}

Pada bagian ini peneliti mendapatkan data yang akurat dan otentik karena dilakukan dengan mengumpulkan sumber data baik data primer dan sekunder, yang disesuaikan dengan pendekatan penelitian. Teknik pengumpulan data primer dan data sekunder yang digunakan adalah :

a. Wawancara Langsung

Wawancara adalah situasi peran antara pribadi bertatap muka, ketika seseorang yakni pewawancara mengajukan pertanyaan-pertanyaan yang dirancang untuk memperoleh jawaban yang relevan dengan masalah penelitian kepada responden. ${ }^{9}$ Wawancara langsung dalam pengumpulan fakta sosial sebagai bahan kajian ilmu hukum empiris, dilakukan dengan cara tanya jawab secara langsung dimana semua pertanyaan disusun secara sistematis, jelas dan terarah sesuai dengan isu hukum, yang diangkat dalam penelitian. Wawancara langsung ini dimaksudkan untuk memperoleh informasi yang benar dan akurat dari sumber yang ditetapkan sebelumnya. Wawancara tersebut semua keterangan yang diperoleh mengenai apa yang

${ }^{9}$ Op.Cit, hal. 82. 
diinginkan dicatat atau direkam dengan baik. ${ }^{10}$ Wawancara dilakukan untuk memperoleh keterangan secara lisan guna mencapai tujuan yaitu mendapatkan informasi yang akurat dari narasumber yang berkompeten.

\section{Analisis Data}

Metode analisis data yang sesuai dengan penelitian ini adalah dengan menggunakan pendekatan secara kualitatif, yaitu analisis data mengungkapkan dan mengambil kebenaran yang diperoleh dari kepustakaan dan penelitian lapangan yaitu dengan menggabungkan antara peraturanperaturan, yurisprudensi, buku-buku ilmiah yang ada hubungannya dengan pembatalan sertifikat pinjam pakai tanah sebagai aset pemerintah,serta keterangan informasi yang diperoleh dengan cara wawancara, kemudian dianalisis secara kualitatif sehingga mendapatkan suatu pemecahannya, dan dapat ditarik kesimpulan.

\section{HASIL DAN PEMBAHASAN}

\section{A. Proses Pembatalan Status Tanah Terhadap Sertifikat Hak Pakai Tanah Sebagai Aset Pemerintah Pada Badan Pertanahan Nasional Kota Samarinda}

Sebelum membahas mengenai pembatalan sertifikat hak pakai tanah, maka perlu diketahui dulu yang menjadi pertimbangan utama atau dasar bagi Badan Pertanahan Nasional Kota Samarinda dalam menerbitkan sertifikat hak pakai tanah diatas tanah negara. Pertimbangan utama atau dasar tersebut dapat ditemukan pada perihal menimbang dalam ketentuan Peraturan Menteri Negeri Agraria/Kepala Badan Pertanahan Nasional Nomor 9 Tahun 1999 Tentang Tata Cara Pemberian Dan Pembatalan Hak Atas Tanah Negara Dan Hak Pengelolaan yang menyatakan bahwa pemberian sertifikat hak pakai tanah diatas tanah negara merupakan implementasi pemberian hak atas tanah sesuai dengan

${ }^{10}$ Bahder Johan Nasution, 2008, Metode Penelitian Ilmu Hukum, Bandung: CV Mandar Maju. hal. 167-168. amanat Undang-undang Nomor 5 Tahun 1960 dan Peraturan Pemerintah Nomor 40 Tahun 1996 perlu diatur mengenai tata cara pemberian dan pembatalan hak atas Tanah Negara dan Hak Pengelolaan.

Setelah memahami dasar pertimbangan diterbitkannya sertifikat hak pakai diatas tanah negara, maka dalam hal kaitannya dengan penelitian penulis terkait tanah negara yang menjadi aset pemerintah dalam hal ini lingkup penelitian penulis Pemerintah Kota Samarinda tersebut dapat terjadi, menurut beliau apabila Pemerintah Kota Samarinda mengajukan pemohonan untuk penerbitan sertifikat hak pakai tanah di atas tanah negara yang belum memiliki alas hak tanah, atau yang lainnya maka Badan Pertanahan Nasional Kota Samarinda dapat menerbitkan sertifikat hak pakai tanah.

Berdasarkan penjelasan tersebut maka menurut beliau wajar bila status tanah negara berubah menjadi aset pemerintah ketika diatasnya telah memiliki alas hak tanah berupa hak pakai dan penggunaannya diperuntukkan sebagai aset pemerintah, selama prosedur pengajuan pemohonan diterbitkan sertifikat hak pakainya sesuai dengan ketentuan aturan Pasal 32 sampai dengan pasal 48 Peraturan Menteri Negeri Agraria/Kepala Badan Pertanahan Nasional Nomor 9 Tahun 1999 Tentang Tata Cara Pemberian Dan Pembatalan Hak Atas Tanah Negara Dan Hak Pengelolaan. Oleh karena itu, berdasarkan hasil wawancara, beliau menyatakan bila ada sertifikat yang diterbitkan tentu sertifikat tersebut juga dapat berakhir, sehingga sertifikat hak pakai tanah yang digunakan oleh Pemerintah Daerah Kota Samarinda sebagai aset daerah tentu penggunaanya juga dapat berakhir. Berakhirnya hak pakai tanah diatas tanah negara tersebut menurut beliau bukanlah tanpa alasan. Beliau menjelaskan bahwa ada beberapa faktor yang mempengaruhi berakhirnya hak pakai tanah diatas tanah negara diantaranya habisnya jangka waktu hak pakai dan adanya pembatalan sertifikat. Hal ini sesuai dengan ketentuan Peraturan Menteri Negeri Agraria/Kepala Badan Pertanahan Nasional Nomor 9 Tahun 1999 Tentang Tata Cara 
Pemberian Dan Pembatalan Hak Atas Tanah Negara Dan Hak Pengelolaan.

Berakhirnya jangka waktu sertifikat hak pakai menurut beliau dapat diperpanjang kembali, dan dasar pertimbangan terkait perpanjangan jangka waktu sertifikat hak pakai tanah pada tanah negara bagi Badan Pertanahan Nasional Kota Samarinda ialah ketentuan Pasal 142 sampai dengan Pasal 149 Peraturan Menteri Negeri Agraria/Kepala Badan Pertanahan Nasional Nomor 9 Tahun 1999 Tentang Tata Cara Pemberian Dan Pembatalan Hak Atas Tanah Negara Dan Hak Pengelolaan. Terkait pembatalan sertifikat hak pakai tanah pada tanah negara dapat dibatalkan, maka berdasarkan hasil wawancara beliau menjelaskan bahwa apabila ada sertifikat hak pakai yang menjadi aset pemerintah dapat diterbitkan, maka juga tentu sertifikat hak pakai yang diajukan oleh pemerintah dalam hal ini lingkup penelitian penulis adalah Pemerintah Kota Samarinda dapat dibatalkan. Proses pembatalannya sendiri juga harus disesuaikan dengan ketentuan aturan Peraturan Menteri Negeri Agraria/Kepala Badan Pertanahan Nasional Nomor 9 Tahun 1999 Tentang Tata Cara Pemberian Dan Pembatalan Hak Atas Tanah Negara Dan Hak Pengelolaan. Berdasarkan hasil penelitian penulis maka dapat penulis jelaskan secara garis besar prosedur pembatalan terhadap sertifikat hak pakai tanah sebagai aset pemerintah serta status tanah akibat pembatalan sertifikat hak pakai tanah sebagai aset pemerintah oleh Badan Pertanahan Nasional Kota Samarinda, sebagai berikut;

\section{Adanya Cacat Hukum \\ Administratif Yang Diterbitkan Karena Pemohonan Pada Badan Pertanahan Nasional Kota Samarinda}

Bahwa sertifikat hak pakai tanah dapat dibatalkan melalui jalur disebabkan adanya cacat administratif oleh Badan Pertanahan Nasional Kota Samarinda, bahkan beliau menambahkan, sekalipun sertifikat hak pakai tersebut diberikan kepada Pemerintah, dalam hal ini seperti misalnya Pemerintah Kota Samarinda untuk menggunakan tanah negara dan tercatat sebagai aset pemerintah, menurut beliau selama konteksnya hanya bersifat hak pakai tentu dapat dibatalkan. Pernyataan tersebut diperkuat dengan adanya ketentuan aturan Pasal 104 ayat 2 Peraturan Menteri Negeri Agraria/Kepala Badan Pertanahan Nasional Nomor 9 Tahun 1999 Tentang Tata Cara Pemberian Dan Pembatalan Hak Atas Tanah Negara Dan Hak Pengelolaan, yang menyatakan bahwa pembatalan hak atas tanah dapat diterbitkan salah satunya karena terdapat cacat hukum administrasi dalam penerbitan keputusan pemberian dan/atau sertipikat hak atas tanahnya.

Penjelasan ketentuan pasal tersebut, seolah menegaskan bahwa penguasaan tanah oleh Pemerintah Kota Samarinda sebagai aset pemerintah yang menjadi lingkup penelitian penulis hanya bersifat temporer dan tidak permanen. Artinya, tanah yang telah memiliki sertifikat hak pakai sebagai bagian dari aset pemerintah tentu dapat dibatalkan dan tidak menjadi milik pemerintah daerah. Hal tersebut diberlakukan untuk semua tanah negara yang tercatat sebagai aset pemerintah dalam hal ini Pemerintah Kota Samarinda yang telah memiliki sertifikat hak pakai.

Lebih lanjut beliau kembali menjelaskan bahwa pembatalan sertifikat hak pakai yang disebabkan karena cacat hukum administratif dapat dilakukan dengan, salah satunya adalah karena adanya pemohonan yang diajukan ke kantor Badan Pertanahan Nasional, dalam hal ini yang menjadi konsentrasi penulis ialah Badan Pertanahan Nasional Kota Samarinda. Hal tersebut telah diatur sesuai ketentuan Peraturan Menteri Negeri Agraria/Kepala Badan Pertanahan Nasional Nomor 9 Tahun 1999 Tentang Tata Cara Pemberian Dan Pembatalan Hak Atas Tanah Negara Dan Hak Pengelolaan, permohonan pembatalan hak atas tanah yang terdapat pada Bab VI Tata Cara Pembatalan Hak Atas Tanah Paragraf ke-1.

Selanjutnya, menurut beliau pembatalan hak atas tanah yang disebabkan karena cacat hukum administatif yang salah satunya disebabkan karena adanya pemohonan dapat diajukan secara tertulis, hal ini sesuai dengan ketentuan aturan Pasal 108 Peraturan Menteri Negeri 
Agraria/Kepala Badan Pertanahan Nasional Nomor 9 Tahun 1999 Tentang Tata Cara Pemberian Dan Pembatalan Hak Atas Tanah Negara Dan Hak Pengelolaan, sedangkan berkaitan dengan ketentuan syarat-syarat pemohonan diatur jelas dalam Pasal 108 ayat 2 dan ayat 3 Peraturan Menteri Negeri Agraria/Kepala Badan Pertanahan Nasional Nomor 9 Tahun 1999 Tentang Tata Cara Pemberian Dan Pembatalan Hak Atas Tanah Negara Dan Hak Pengelolaan.

Selain mengajukan secara tertulis, dan melengkapi persyaratan pemohonan, beliau menambahkan bahwa pengajuan tersebut juga harus dilengkapi dengan adanya alasan pemohonan yang harus dilampirkan saat mengajukan pemohonan. Hal ini sesuai dengan ketentuan aturan Pasal 109 Peraturan Menteri Negeri Agraria/Kepala Badan Pertanahan Nasional Nomor 9 Tahun 1999 Tentang Tata Cara Pemberian Dan Pembatalan Hak Atas Tanah Negara Dan Hak Pengelolaan. Berkaitan dengan alasan pemohonan tersebut, maka menurut beliau substansi dalil pemohonan itu harus disesuaikan dengan ketentuan aturan Pasal 107 ayat 1 Peraturan Menteri Negeri Agraria/Kepala Badan Pertanahan Nasional Nomor 9 Tahun 1999 Tentang Tata Cara Pemberian Dan Pembatalan Hak Atas Tanah Negara Dan Hak Pengelolaan, yaitu;

a. Kesalahan Prosedur;

b. Kesalahan penerapan peraturan perundang-undangan;

c. Kesalahan Subyek hak;

d. Kesalahan obyek hak;

e. Kesalahan jenis hak;

f. Kesalahan perhitungan luas;

g. Terdapat tumpang tindih hak atas tanah;

h. Terdapat ketidakbenaran pada data fisik dan/atau data yuridis; atau

i. Kesalahan lainnya yang bersifat hukum administratif.

Selanjutnya, menurut beliau dalil pemohonan yang disesuaikan dengan kriteria kesalahan administratif pada Pasal Pasal 107 ayat 1 Peraturan Menteri Negeri Agraria/Kepala Badan Pertanahan Nasional Nomor 9 Tahun 1999 Tentang Tata Cara
Pemberian Dan Pembatalan Hak Atas Tanah Negara Dan Hak Pengelolaan akan diperiksa kembali oleh Kepala Kantor Pertanahan dalam hal ini sesuai lingkup penelitian penulis Badan Pertanahan Nasional Kota Samarinda sebagai yang mewakili Menteri Negara Agraria.

Pemeriksaan dalil pemohonan tersebut akan dilakukan setelah pemohon yang bersangkutan mengajukan kepada Menteri Negara Agraria yang diwakili oleh Kepala Kantor Pertanahan, dan beliau menegaskan pengajuan pemohonan kepada Kepala Kantor Pertanahan yang mewakili Menteri Negara Agraria harus disesuaikan dengan keberadaan letak tanah tersebut. Hal ini sesuai dengan ketentuan Pasal 110 Peraturan Menteri Negeri Agraria/Kepala Badan Pertanahan Nasional Nomor 9 Tahun 1999 Tentang Tata Cara Pemberian Dan Pembatalan Hak Atas Tanah Negara Dan Hak Pengelolaan.

Oleh karena itu, beliau menegaskan terkait kewenangan wilayah ini bahwa bila ada satu permohonan pembatalan maka hanya berlaku untuk satu atau beberapa hak atas tanah tertentu yang letaknya dalam satu Kabupaten.Kota, sehingga apabila ada pengajuan pemohonan pembatalan sertifikat hak pakai tanah dalam hal ini yang menjadi kaitan dari penelitian penulis adalah tanah negara yang diterbitkan sertifikat hak pakai tanahnya dan menjadi aset Pemerintah Kota Samarinda, pengajuan tersebut harus diajukan ke kantor pertanahan Badan Pertanahan Nasional Kota Samarinda, dan pengajuan pemohonan tersebut hanya berlaku untuk tanah negara yang telah bersertifikat hak pakai serta tercatat sebagai aset pemerintah dan wilayah tanah tersebut berada di Kota Samarinda. Hal ini sesuai dengan ketentuan Pasal 111 ayat 2 Peraturan Menteri Negeri Agraria/Kepala Badan Pertanahan Nasional Nomor 9 Tahun 1999 Tentang Tata Cara Pemberian Dan Pembatalan Hak Atas Tanah Negara Dan Hak Pengelolaan.

Setelah pengajuan berkas pemohonan diterima, berdasarkan ketentuan Pasal 111 Peraturan Menteri Negeri Agraria/Kepala Badan Pertanahan Nasional Nomor 9 Tahun 1999 Tentang Tata Cara Pemberian Dan Pembatalan Hak Atas Tanah Negara 
Dan Hak Pengelolaan, bahwa Kepala Kantor Pertanahan akan memeriksa dan meneliti data yuridis dan data fisik, lalu kemudian mencatat dalam formulir isian, dan memberikan tanda terima berkas permohonan sesuai formulir isian, kemudian memberitahukan kepada pemohon untuk melengkapi data yuridis dan data fisik apabila masih diperlukan.

Setelah permohonan di teliti kelengkapan dan kebenaran data yuridis dan data fisik permohonan pembatalan hak atas tanah oleh Kepala Kantor Pertanaan, maka dalam hal keputusan pembatalan hak telah dilimpahkan kepada Kepala Kantor wilayah dengan menyampaikan berkas permohonan yang dimaksud kepada Kepala Kantor Wilayah disertai dengan pendapat dan pertimbangannya. Hal ini sesuai dengan ketentuan Pasal 112 Peraturan Menteri Negeri Agraria/Kepala Badan Pertanahan Nasional Nomor 9 Tahun 1999 Tentang Tata Cara Pemberian Dan Pembatalan Hak Atas Tanah Negara Dan Hak Pengelolaan.

Setelah menerima berkas permohonan yang disertai pendapat dan pertimbangan Kepala Kantor Wilayah memerintahkan kepada Kepala Bidang Hak Atas Tanah untuk mencatat dalam formulir isian, dan memeriksa serta meneliti kelengkapan data yuridis dan data fisik, sehingga apabila belum lengkap segera meminta Kepala Kantor Pertanahan untuk melengkapinya.

Lebih lanjut beliau menjelaskan apabila ditemukan kekurangan oleh Kepala Kantor Wilayah maka dikembalikan kepada Kepala Kantor Pertanahan untuk diteliti lagi kelengkapan dan kebenaran data yuridis dan data fisik atas tanah yang dimohon pembatalannya beserta pendapat dan pertimbangan serta memeriksa kelayakan permohonan tersebut dapat atau tidaknya dikabulkan, apabila berkas tersebut telah lengkap maka dilimpahkan kembali kepada Kepala Kantor Wilayah dalam hal keputusan pembalan sertifikat hak pakai tersebut, yang mana Kepala Kantor Wilayah akan menerbitkan keputusan pembatalan hak atas tanah yang dimohon atau keputusan penolakan yang disertai dengan alasan penolakannya. Hal ini sesuai dengan ketentuan Pasal 113 Peraturan Menteri Negeri Agraria/Kepala Badan Pertanahan Nasional Nomor 9 Tahun 1999 Tentang Tata Cara Pemberian Dan Pembatalan Hak Atas Tanah Negara Dan Hak Pengelolaan. Selain itu, mengenai pelimpahan kewenangan dalam menerbitkan keputusan pembatalan hak atas tanah menurut beliau kembali menjelaskan bahwa bukan hanya Kepala Kantor Wilayah yang dapat menerbitkan keputusan pembatalan hak atas tanah tersebut, namun juga dapat dilimpahkan langsung oleh Kepala Kantor Pertanahan kepada Menteri disertai pendapat dan pertimbangannya, sehingga apabila ada sertifikat hak pakai tanah yang diajukan permohonan pembatalan hak atas tanahnya di Kota Samarinda, kemudian berdasarkan pertimbangan Kepala Kantor Pertanahan Kota Samarinda berkas permohonan tersebut harus dilimpahkan kepada Menteri Negara Agraria, maka keputusan pembatalan terhadap sertifikat hak pakai dapat langsung dikeluarkan oleh Menteri Negara Agraria. Hal ini sesuai dengan ketentuan Pasal 114 Peraturan Menteri Negeri Agraria/Kepala Badan Pertanahan Nasional Nomor 9 Tahun 1999 Tentang Tata Cara Pemberian Dan Pembatalan Hak Atas Tanah Negara Dan Hak Pengelolaan. Secara garis besar pelimpahan kewenangan keputusan pembatalan terhadap sertifikat hak pakai kepada Menteri Negara Agraria memiliki prosedur yang sama dengan pelimpahan kewenangan keputusan pembatalan terhadap sertifikat hak pakai kepada Kepala Kantor Wilayah. Hal ini dapat terlihat pada Pasal 115 sampai dengan Pasal 117 Peraturan Menteri Negeri Agraria/Kepala Badan Pertanahan Nasional Nomor 9 Tahun 1999 Tentang Tata Cara Pemberian Dan Pembatalan Hak Atas Tanah Negara Dan Hak Pengelolaan.

Dalam hal ini beliau menerangkan bentuk dari pembatalan sertifikat hak pakai tanah pada tanah negara karena cacat administratif yang disebabkan permohonan berupa surat keputusan pembatalan hak atau surat keputusan penolakan pembatalan yang dikeluarkan oleh Kepala Badan Pertanahan Nasional. Hal ini sesuai dengan Pasal 118 Peraturan Menteri Negeri 
Agraria/Kepala Badan Pertanahan Nasional Nomor 9 Tahun 1999 Tentang Tata Cara Pemberian Dan Pembatalan Hak Atas Tanah Negara Dan Hak Pengelolaan, dan juga ditegaskan kembali dalam Pasal 56 ayat 3 Peraturan Menteri Agraria Dan Tata Ruang/ Kepala Badan Pertanahan Nasional Republik Indonesia Nomor 11 Tahun 2016 Tentang Penyelesaian Kasus Pertanahan.

\section{Adanya Cacat Hukum Administratif Yang Diterbitkan Tanpa Pemohonan Pada Badan Pertanahan Nasional Kota Samarinda.}

Berdasarkan hasil wawancara dengan Bapak Muhammad Aidi, SH selaku Kepala Sub Bagian Tata Usaha pada Badan Pertanahan Nasional Kota Samarinda,bahwa beliau menjelaskan kembali selain pembatalan sertifikat hak pakai karena cacat hukum administratif dapat dilakukan karena adanya pemohonan, dalam ketentuan aturan Peraturan Menteri Negeri Agraria/Kepala Badan Pertanahan Nasional Nomor 9 Tahun 1999 Tentang Tata Cara Pemberian Dan Pembatalan Hak Atas Tanah Negara Dan Hak Pengelolaan juga memberikan kewenangan untuk membatalkan hak atas tanah apabila ditemukan cacat hukum administratif tanpa adanya pemohonan. Hal ini berdasarkan ketentuan Pasal 119 Peraturan Menteri Negeri Agraria/Kepala Badan Pertanahan Nasional Nomor 9 Tahun 1999 Tentang Tata Cara Pemberian Dan Pembatalan Hak Atas Tanah Negara Dan Hak Pengelolaan. Sesuai ketentuan pasal tersebut bahwa pemberian kewenangan pembatalan hak atas tanah tanpa adanya pemohonan dilakukan oleh pejabat yang berwenang. Maksud dari pejabat yang berwenang ini ialah pejabat yang berada dalam lingkup kerja bidang pertanahan yaitu Pejabat Yang Berkedudukan di Badan Pertanahan Nasional. Untuk prosedur pembatalan sertifikat hak pakai karena cacat hukum administratif yang disebabkan tanpa adanya pemohonan, hampir sama dengan prosedur pembatalan sertifikat karena cacat hukum administratif yang dapat diajukan karena adanya pemohonan, yang berbeda hanyalah pada point tidak adanya prosedur pemohonan syarat pengajuan, sehingga langsung diproses oleh Kepala Kantor Pertanahan dalam hal ini lingkup penelitian penulis adalah Badan Pertanahan Nasional Kota Samarinda yang selanjutnya akan langsung mengadakan penelitian data yuridis, dan data fisik apabila diketahui adanya cacat hukum administratif dalam proses penerbitannya. Hal ini sesuai dengan pasal 120 ayat 1 Peraturan Menteri Negeri Agraria/Kepala Badan Pertanahan Nasional Nomor 9 Tahun 1999 Tentang Tata Cara Pemberian Dan Pembatalan Hak Atas Tanah Negara Dan Hak Pengelolaan. Merujuk pada ketentuan pasal tersebut, beliau menambahkan meskipun tanpa pemohonan bukan berarti tidak serta merta dapat dibatalkan bila tidak adanya dalil atau dasar yang kuat dalam pembatalan sertifikat hak pakai tersebut, maka dalam hal ini tetap harus menyesuaikan kriteria kesalahan cacat hukum administratif yang menjadi dalil pembatalan sertifikat hak pakai tanpa pemohonan tersebut.

Kriteria kesalahan cacat hukum administratif yang dimaksud dalam hal ini ialah ketentuan aturan Pasal 107 ayat 1 Peraturan Menteri Negeri Agraria/Kepala Badan Pertanahan Nasional Nomor 9 Tahun 1999 Tentang Tata Cara Pemberian Dan Pembatalan Hak Atas Tanah Negara Dan Hak Pengelolaan, yaitu;

a. Kesalahan Prosedur;

b. Kesalahan penerapan peraturan perundang-undangan;

c. Kesalahan Subyek hak;

d. Kesalahan obyek hak;

e. Kesalahan jenis hak;

f. Kesalahan perhitungan luas;

g. Terdapat tumpang tindih hak atas tanah;

h. Terdapat ketidakbenaran pada data fisik dan/atau data yuridis; atau

i. Kesalahan lainnya yang bersifat hukum administratif.

Selanjutnya, setelah adanya hasil penelitian, maka hasil penelitian tersebut dapat disampaikan kepada Kepala Kantor Wilayah atau kepada Menteri untuk diusulkan pembatalannya disertai dengan pendapat dan pertimbangannya. Hal ini sesuai dengan pasal 120 ayat 2 Peraturan Menteri Negeri Agraria/Kepala Badan Pertanahan Nasional Nomor 9 Tahun 1999 
Tentang Tata Cara Pemberian Dan Pembatalan Hak Atas Tanah Negara Dan Hak Pengelolaan. Menurut beliau bentuk pembatalan sertifikat hak pakai tanah karena cacat hukum administratif yang disebabkan tanpa adanya pemohonan serupa dengan bentuk pembatalan sertifikat hak pakai tanah karena cacat hukum administratif yang disebabkan karena adanya pemohonan yaitu berupa surat keputusan pembatalan hak atau surat keputusan penolakan pembatalan.

Selanjutnya, beliau menambahkan bahwa surat keputusan pembatalan hak atau surat keputusan penolakan pembatalan yang dikeluarkan oleh Kepala Badan Pertanahan Nasional disampaikan kepada pemohon atau yang bersangkutan melalui surat tercatat atau dengan cara lain yang menjamin sampainya keputusan tersebut kepada yang berhak. Hal ini sesuai dengan Pasal 123 Peraturan Menteri Negeri Agraria/Kepala Badan Pertanahan Nasional Nomor 9 Tahun 1999 Tentang Tata Cara Pemberian Dan Pembatalan Hak Atas Tanah Negara Dan Hak Pengelolaan.

\section{Adanya Putusan Pengadilan Berkekuatan Hukum Tetap Pada Badan Pertanahan Nasional Kota Samarinda}

Selain dapat dibatalkan karena cacat administratif, prosedur pembatalan sertifikat hak pakai dapat pula dibatalkan karena penetapan putusan pengadilan yang telah memperoleh kekuatan hukum tetap. Beliau menjelaskan bahwa keputusan pembatalan hak atas tanah karena melaksanakan putusan pengadilan yang telah memperoleh kekuatan hukum tetap diterbitkan atas pemohonan yang berkepentingan, dan amar putusan pengadilan yang telah memperoleh kekuatan hukum tetap berbunyi mengenai dinyatakan batal atau tidak mempunyai kekuatan hukum atau yang pada intinya sama dengan itu. Hal ini sesuai dengan Pasal 124 Peraturan Menteri Negeri Agraria/Kepala Badan Pertanahan Nasional Nomor 9 Tahun 1999 Tentang Tata Cara Pemberian Dan Pembatalan Hak Atas Tanah Negara Dan Hak Pengelolaan. Oleh karena itu, beliau menegaskan meskipun putusan pengadilan telah terbit apabila tidak diajukan pemohonan pembatalan haknya ke Badan Pertanahan Nasional, tetap tidak dapat dilaksanakan amar putusan pengadilan tersebut meskipun sudah mempunyai kekuatan hukum, sehingga harus ada pemohonan pembatalan sertifikat hak pakai tanah karena melaksanakan putusan pengadilan yang telah memperoleh kekuatan hukum tetap yang mana putusan pengadilan tersebut diajukan langsung kepada Menteri atau Kepala Kantor Wilayah atau melalui Kepala Kantor Pertanahan itu bersifat wajib. Hal ini sesuai dengan Pasal 125 ayat (1) Peraturan Menteri Negeri Agraria/Kepala Badan Pertanahan Nasional Nomor 9 Tahun 1999 Tentang Tata Cara Pemberian Dan Pembatalan Hak Atas Tanah Negara Dan Hak Pengelolaan. Menurut beliau kekuatan hukum putusan pengadilan tersebut hanya berlaku untuk satu sertifikat hak pakai yang ingin dibatalkan, sehingga satu putusan pengadilan hanya mendapatkan satu pemohonan pembatalan dan wilayahnya hanya berada dalam satu kota. Hal ini sesuai pula dengan Pasal 125 ayat 2 Peraturan Menteri Negeri Agraria/Kepala Badan Pertanahan Nasional Nomor 9 Tahun 1999 Tentang Tata Cara Pemberian Dan Pembatalan Hak Atas Tanah Negara Dan Hak Pengelolaan.

Mengenai tata cara pemohonan pembatalan sertifikat hak pakai tanah karena melaksanakan putusan pengadilan yang telah memperoleh kekuatan hukum tetap, berdasarkan penjelasan beliau, secara garis besar memiliki kesamaan dengan pemohonan pembatalan hak karena cacat administratif yang mana syarat-syarat permohonan pembatalan hak tersebut harus sesuai dengan ketentuan Pasal 126 Peraturan Menteri Negeri Agraria/Kepala Badan Pertanahan Nasional Nomor 9 Tahun 1999 Tentang Tata Cara Pemberian Dan Pembatalan Hak Atas Tanah Negara Dan Hak Pengelolaan.

Selain itu kesamaan yang lainnya adalah pemohonan yang diajukan melalui Kepala Kantor Pertanahan, dengan menerima berkas permohona dan melakukan pemeriksaan dan penelitian kelengkapan data yuridis dan data fisik, mencatat dalam formulir isi, memberikan 
tanda terima berkas permohonan pembatalan, dan memberitahukan kepada pemohon untuk melengkapi data yuridis dan fisik jika masih diperlukan. Hal ini sesuai dengan Pasal 127 Peraturan Menteri Negeri Agraria/Kepala Badan Pertanahan Nasional Nomor 9 Tahun 1999 Tentang Tata Cara Pemberian Dan Pembatalan Hak Atas Tanah Negara Dan Hak Pengelolaan. Selanjutnya Kepala Kantor Pertanahan dalam hal ini sesuai lingkup penelitian penulis Badan Pertanahan Nasional Kota Samarinda meneliti kelengkapan dan kebenaran data yuridis dan data fisik permohonan pembatalan hak atas tanah serta mencocokkan hak atas tanah dengan amar putusan pengadilan dengan data yuridis yang terakhir sebelum diproses lebih lanjut sesuai dengan ketentuan peraturan perundang-undangan yang berlaku. Lebih lanjut dijelaskan oleh beliau, apabila berkas dianggap telah lengkap tetapi ternyata terdapat perbedaan antara data yuridis dan data fisik dengan amar putusan pengadilan, Kepala Kantor Pertanahan dalam hal ini sesuai lingkup penelitian penulis Badan Pertanahan Nasional Kota Samarinda menyampaikan berkas pemohonan tersebut disertai dengan keterangan mengenai perbedaan dimaksud kepada Menteri Negara Agraria. Hal ini sesuai dengan Pasal 128 Peraturan Menteri Negeri Agraria/Kepala Badan Pertanahan Nasional Nomor 9 Tahun 1999 Tentang Tata Cara Pemberian Dan Pembatalan Hak Atas Tanah Negara Dan Hak Pengelolaan. Selanjutnya, apabila Menteri Negara Agraria telah menerima berkas pemohonan dan keterangan, maka Menteri Negara Agraria memerintahkan kepada Pejabat yang ditunjuk untuk mencatat dalam formulir isian, memeriksa dan meneliti kelengkapan data yuridis dan data fisik, dan apabila belum lengkap segera meminta Kepala Kantor Pertanahan dalam hal ini sesuai lingkup penelitian penulis Badan Pertanahan Nasional Kota Samarinda untuk melengkapinya. Beliau juga menambahkan kembali bahwa keberadaan amar putusan pengadilan tetap harus diteliti kembali oleh Menteri Negara Agraria terkait kelengkapan dan kebenaran data yuridis dan data fisik permohonan serta memeriksa kelayakan permohonan untuk dapat dinyatakan apakah amar putusan pengadilan tersebut dapat dilaksanakan. Hal ini sesuai dengan Pasal 129 dan ayat 1, ayat 2, dan ayat 3, serta Pasal 129 dan ayat 1 , ayat 2, dan ayat 3 Peraturan Menteri Negeri Agraria/Kepala Badan Pertanahan Nasional Nomor 9 Tahun 1999 Tentang Tata Cara Pemberian Dan Pembatalan Hak Atas Tanah Negara Dan Hak Pengelolaan.

Setelah pemeriksaan tersebut Menteri Negara Agraria memutuskan pemohonan tersebut apakah menerbitkan keputusan pembatalan hak atas tanah yang dimohon atau memberitahukan bahwa amar putusan pengadilan tidak dapat dilaksanakan disertai dengan alasan dan pertimbangannya. Dalam hal ini, Menteri Negara Agraria tidak dapat melaksanakan amar putusan pengadilan dapat mohon fatwa kepada Mahkamah Agung dalam pelaksanaan amar putusan pengadilan yang dimaksud. Hal ini sesuai dengan Pasal 129 ayat 4, dan ayat 5, serta Pasal 131 ayat 4, dan ayat 5 Peraturan Menteri Negeri Agraria/Kepala Badan Pertanahan Nasional Nomor 9 Tahun 1999 Tentang Tata Cara Pemberian Dan Pembatalan Hak Atas Tanah Negara Dan Hak Pengelolaan. Berkaitan dengan bentuk pembatalan sertifikat hak pakai tanah karena putusan pengadilan, menurut penjelasan beliau bentuknya serupa dengan bentuk pembatalan sertifikat hak pakai tanah karena cacat administratif yaitu berupa surat keputusan pembatalan hak atas tanah atau keputusan tidak melaksanakan putusan pengadilan yang telah memperoleh kakuatan hukum tetap yang kemudian disampaikan kepada pemohon memalui surat tercatat cacat dengan cara lain yang menjamin sampainya keputusan tersebut kepada yang berhak. Hal ini sesuai dengan Pasal 133 Peraturan Menteri Negeri Agraria/Kepala Badan Pertanahan Nasional Nomor 9 Tahun 1999 Tentang Tata Cara Pemberian Dan Pembatalan Hak Atas Tanah Negara Dan Hak Pengelolaan. Berdasarkan penjelasan tersebut, beliau menerangkan bahwa prosedur pembatalan sertifikat hak pakai tanah pada tanah negara jika melalui putusan pengadilan harus diajukan terlebih dahulu ke Badan 
Pertanahan Nasional untuk diteliti kembali hingga dapat diputuskan untuk mengeluarkan Surat Keputusan Pembatalan Hak Atas Tanah oleh Badan Pertanahan Nasional, sehingga prosedur pembatalan sertifikat hak pakai tanah karena putusan pengadilan dapat terwujud apabila ada pemohonan dari yang berkepentingan yang kemudian dikeluarkannya Surat Keputusan Pembatalan Hak Atas Tanah oleh Badan Pertanahan Nasional.

4. Status Tanah Akibat Pembatalan Sertifikat Hak Pakai Tanah Sebagai Aset Pemerintah Pada Badan Pertanahan Nasional Kota Samarinda

Bahwa mengenai kedudukan proses pembatalan sertifikat hak pakai tanah ini yang mana proses pembatalan sertifikat hak pakai tanah ini diberlakukan secara keseluruhan. Artinya, tidak ada pengecualian termasuk proses pembatalan sertifikat hak pakai dapat terjadi bila sertifikat hak pakai tersebut berada diatas tanah negara, sehingga berdasarkan pernyataan beliau maka menurut pengamatan penulis, proses pembatalan sertifikat hak pakai tanah yang berada diatas tanah negara juga dapat terjadi sekalipun tanah negara tersebut telah diinventarisir sebagai aset pemerintah dalam hal ini yang menjadi konsentrasi peneliti adalah Pemerintah Kota Samarinda.

Berdasarkan pernyataan tersebut, maka timbul pertanyaan bagaimana status tanah akibat pembatalan sertifikat hak pakai tanah tersebut. Untuk menjawabnya penulis melakukan pengamatan mengenai perubahan status hak atas tanah khususnya perubahan status tanah yang beralaskan hak pakai. Berdasarkan hasil wawancara dan beberapa teori serta peraturan perundangundangan yang penulis baca, maka dapat penulis jelaskan bahwa status tanah khususnya status tanah yang beralaskan hak pakai dapat berubah. Dalam hal ini adanya peralihan hak tanah khususnya hak pakai dapat ditingkatkan menjadi hak lain selain hak pakai. Dengan kata lain, status tanah hak pakai dapat ditingkatkan menjadi hak lain seperti hak milik, terkait mekanisme peningkatan status dari hak pakai tanah diatas tanah negara menjadi hak atas tanah yang lain, berdasarkan penjelasan beliau harus sesuai dengan ketentuan peraturan perundang-undangan yang berlaku. Dalam hal ini bila tanah yang diajukan sebelumnya beralaskan hak pakai sudah memiliki alas hak lain sebelum ada hak pakai bukan murni tanah negara maka dapat menggunakan ketentuan aturan Keputusan Menteri Negara Agraria/ Kepala Badan Pertanahan Nasional Nomor 6 Tahun 1998 Tentang Pemberian Hak Milik Atas Tanah Untuk Rumah Tinggal, dan dalam ketentuan peraturan tersebut peningkatan status tanah hak pakai. Ketentuan aturan tersebut menjelaskan bahwa status tanah hak pakai dapat ditingkatkan menjadi hak milik bukan hak lain seperti hak guna bangunan atau hak guna usaha.

Lebih lanjut penulis jelaskan, sedangkan untuk tanah yang diajukan sebelumnya tidak ada alas hak dan merupakan tanah negara maka peralihan hak atau peningkatan status hak atas tanahnya harus sesuai dengan ketentuan aturan Peraturan Menteri Negeri Agraria/Kepala Badan Pertanahan Nasional Nomor 9 Tahun 1999 Tentang Tata Cara Pemberian Dan Pembatalan Hak Atas Tanah Negara Dan Hak Pengelolaan, dengan catatan peningkatan status tanah hak pakai ini bukan ditingkatkan menjadi hak milik, hingga saat ini penulis belum menemukan adanya aturan yang bersinergi dengan pernyataan bahwa sertifikat hak pakai pada tanah negara dapat ditingkatkan menjadi hak milik. Penulis hanya menemukan aturan bahwa tanah negara dapat menjadi hak milik apabila belum adanya pengajuan alas hak tanah diatas tanah negara, dan memiliki histori yang harus dibuktikan yang sesuai dengan persyaratan-persyaratan yang terdapat pada ketentuan aturan Peraturan Menteri Negeri Agraria/Kepala Badan Pertanahan Nasional Nomor 9 Tahun 1999 Tentang Tata Cara Pemberian Dan Pembatalan Hak Atas Tanah Negara Dan Hak Pengelolaan. Beliau kembali menjelaskan bahwa terkait status tanah yang belum ada hak alas tanah dan dinyatakan sebagai tanah negara tidak dapat dihapus, sehingga tanah negara akan tetap menjadi hak negara menguasai tanah secara langsung. Oleh karena itu menurut 
analisa penulis, apabila ada pembatalan sertifikat hak pakai tanah diatas tanah negara yang telah tercatat sebagai aset pemerintah dalam hal ini lingkup penelitian penulis adalah Pemerintah Kota Samarinda, maka akibat dari pembatalan sertifikat hak pakai tanah sebagai aset pemerintah tersebut adalah status tanah yang berubah. Dalam hal ini penulis merujuk pada Pasal 56 ayat 1 Peraturan Pemerintah Nomor 40 Tahun 1996 tentang Hak Guna Usaha, Hak Guna Bangunan Dan Hak Pakai Atas Tanah yang menyatakan bahwa, status tanah tersebut kembali menjadi tanah negara. Maksud dari kata hapusnya hak pakai, kemudian dijelaskan kembali secara lugas dalam Pasal 55 ayat 1 point a dan poin $b$ Peraturan Pemerintah Nomor 40 Tahun 1996 tentang Hak Guna Usaha, Hak Guna Bangunan Dan Hak Pakai Atas Tanah, yang menjelaskan bahwa yang termasuk dari hapusnya hak pakai diantaranya ialah berakhirnya jangka waktu sebagaimana ditetapkan dalam keputusan pemberian atau perpanjangannya atau dalam perjanjian pemberiannya, dan dibatalkan oleh pejabat yang berwenang. Dalam hal kaitannnya, tanah negara yang telah memiliki alas hak tanah berupa hak pakai dan telah tercatat sebagai aset pemerintah dalam hal ini lingkup penelitian penulis adalah Pemerintah Kota Samarinda, maka merujuk pada ketentuan aturan Pasal 57 ayat 1 Peraturan Menteri Agraria Dan Tata Ruang/ Kepala Badan Pertanahan Nasional Republik Indonesia Nomor 11 Tahun 2016 Tentang Penyelesaian Kasus Pertanahan, bahwa pelaksanaan pembatalan hak atas tanahnya dilakukan tanpa menunggu proses penghapusan aset atau aktiva tetap dari Pemerintah Daerah. Lebih lanjut dapat penulis jelaskan, merujuk pada ketentuan aturan Pasal 57 ayat 2 Peraturan Menteri Agraria Dan Tata Ruang/ Kepala Badan Pertanahan Nasional Republik Indonesia Nomor 11 Tahun 2016 Tentang Penyelesaian Kasus Pertanahan, bahwa setelah dilaksanakannya pembatalan Kepala Kantor Pertanahan memberitahukan kepada pemegang aset yang hak atas tanahnya dibatalkan agar dilakukan penghapusan aset atau aktiva tetap. Selain itu dapat penulis jelaskan terkait peningkatan status tanah yang telah menjadi aset pemerintah, bahwa apabila pemerintah dalam hal ini lingkup penelitian penulis adalah Pemerintah Kota Samarinda ingin meningkatkan status tanah yang memiliki alas hak pakai dan diperuntukkan sebagai inventarisasi aset pemerintah dalam hal ini lingkup penelitian penulis adalah Pemerintah Kota Samarinda tidak dapat terjadi.

Hal ini karena kewenangan Pemerintah Daerah dalam hal ini lingkup penelitian penulis adalah Pemerintah Kota Samarinda hanya sebatas menguasai tanah bukan memiliki yang kemudian tanah negara tersebut dikonversi menjadi hak pakai tanah, dan peningkatan sertifikat hak pakai tidak dapat dilakukan diatas tanah negara kecuali belum ada alas hak diatas tanah negara tersebut. Berdasarkan uraian penjelasan tersebut, maka dapat penulis simpulkan secara garis besar bahwa prosedur pembatalan terhadap sertifikat hak pakai tanah yang tercatat sebagai aset pemerintah dalam hal ini lingkup penelitian penulis adalah Pemerintah Kota Samarinda, dapat dilakukan oleh Badan Pertanahan Nasional Kota Samarinda berdasarkan ketentuan aturan Peraturan Menteri Negeri Agraria/Kepala Badan Pertanahan Nasional Nomor 9 Tahun 1999 Tentang Tata Cara Pemberian Dan Pembatalan Hak Atas Tanah Negara Dan Hak Pengelolaan, apabila ditemukan dua hal yaitu adanya cacat hukum administratif, dan adanya putusan pengadilan yang memperoleh kekuatan hukum tetap, yang kemudian mengeluarkan Surat Keputusan Pembatalan Sertifikat Hak Atas Tanah, sedangkan terkait mengenai status tanah akibat pembatalan sertifikat hak pakai tanah yang menjadi aset pemerintah dalam hal ini lingkup penelitian penulis adalah Pemerintah Kota Samarinda, ialah kembali menjadi tanah negara yang mana dalam hal ini Badan Pertanahan Nasional Kota Samarinda tidak perlu menunggu dicoretnya tanah negara dari aset pemerintah karena dengan dikeluarkannya Surat Keputusan Pembatalan Sertifikat Hak Atas Tanah, maka status tanah tersebut kembali menjadi tanah yang langsung dikuasai oleh negara. 


\section{B. Kendala Yang Dihadapi Badan Pertanahan Nasional Kota Samarinda Dalam Proses Pembatalan Sertifikat Hak Pakai Tanah Sebagai Aset Pemerintah Kota Samarinda}

Dalam proses pembatalan sertifikat hak pakai tanah diatas tanah negara yang menjadi aset pemerintah dalam hal ini lingkup penelitian penulis adalah Pemerintah Kota Samarinda tentu menemukan kendala atau hambatan dalam menyelesaikan prosedur pembatalan sertifikat hak pakai tanah sebagai aset pemerintah di Kota Samarinda. Kendala tersebut dapat penulis jelaskan sebagai berikut;

\section{Tidak Adanya Pengajuan \\ Pemohonan}

Salah satu tantangan terbesar bagi Badan Pertanahan Nasional dalam lingkup penelitian ini Badan Pertanahan Nasional Kota Samarinda adalah tidak aktifnya pemohon mengajukan pemohonan tehadap pembatalan sertifikat hak pakai tanah. Dalam hal kaitannya dengan penelitian penulis mengenai pembatalan sertifikat hak atas tanah yang menjadi aset pemerintah dalam lingkup penelitian ini ialah Pemerintah Kota Samarinda, maka jarang ditemukan adanya pemohon yang mengajukan cacat hukum administratif terhadap tanah negara yang tercatat sebagai aset pemerintah dalam lingkup penelitian ini ialah Pemerintah Kota Samarinda.

Hal ini menurut beliau sekali lagi disebabkan oleh tidak aktifnya pemohon mengajukan pemohonan, sehingga sulit bagi Badan Pertanahan Nasional dalam lingkup penelitian ini Badan Pertanahan Nasional Kota Samarinda memproses pembatalan sertifikat hak pakai tanah diatas tanah negara yang menjadi aset pemerintah dalam lingkup penelitian ini ialah Pemerintah Kota Samarinda. Begitu pula dengan pemohonan yang diajukan berdasarkan putusan pengadilan yang memperoleh kekuatan hukum tetap. Dalam hal ini menurut beliau yang harus mengajukan adalah yang memenangkan putusan pengadilan tersebut agar dapat diproses oleh Badan Pertanahan Nasional dalam lingkup penelitian ini Badan
Pertanahan Nasional Kota Samarinda untuk dibatalkannya sertifikat pembatalan hak atas tanah tersebut. Lebih lanjut beliau menambahkan, hal ini juga berlaku untuk sertifikat hak atas tanah yang menjadi aset pemerintah dalam lingkup penelitian ini ialah Pemerintah Kota Samarinda, apabila ada pengajuan pemohonan pelaksanaan putusan pengadilan yang memperoleh kekuatan hukum tetap, maka Badan Pertanahan Nasional dalam lingkup penelitian ini Badan Pertanahan Nasional Kota Samarinda akan melaksanakan prosedur pembatalan sertifikat hak pakai tanah meskipun telah tercatat sebagai aset pemerintah.

Dalam hal pengajuan pemohonan karena putusan pengadilan merupakan hal yang paling sering menjadi kendala bagi Badan Pertanahan Nasional dalam lingkup penelitian ini Badan Pertanahan Nasional Kota Samarinda akan menyelesaikan prosedur pembatalan sertifikat hak pakai tanah. Menurut beliau adanya kesalahpahaman oleh masyarakat terhadap kedudukan putusan pengadilan tersebut. Dalam hal ini Badan Pertanahan Nasional dalam lingkup penelitian ini Badan Pertanahan Nasional Kota Samarinda tidak dapat menindaklanjuti apabila belum ada yang mengajukan pemohonan bedasarkan putusan pengadilan tersebut untuk membatalkan sertifikat hak pakai tanah meskipun putusan pengadilan tersebut sudah memiliki kekuatan hukum tetap.

Dalam konteks ini, menurut pemahaman penulis, beliau menyamakan proses pembatalan sertifikat hak pakai tanah diatas tanah negara dengan tanah yang telah memiliki alas hak tanah. Artinya, prosedur pembatalan sertifikat hak pakai diatas tanah negara dapat terjadi apabila ada pemohonan yang diajukan baik melalui cacat administrasi maupun putusan pengadilan, sehingga menurut beliau sangat sulit memprediksi sertifikat hak pakai yang mana yang bermasalah dan harus dibatalkan.

Terlebih lagi, apabila sertifikat hak pakai pada tanah negara tersebut merupakan aset dari pemerintah seperti Pemerintah Kota Samarinda. Beliau menegaskan bahwa, harus ada pemohon 
dalam mengajukan prosedur pembatalan sertifikat hak pakai termasuk sertifikat hak pakai pada tanah negara sebagai aset pemerintah, sehingga hal ini menjadi kendala yang dihadapi oleh Badan Pertanahan Nasional Kota Samarinda terkait menemukan sertifikat hak pakai tanah diatas tanah negara yang bermasalah dan harus diberikan surat keputusan pembatalan hak atas tanah.

\section{Badan Pertanahan Nasional Kota Samarinda Bersifat Pasif .}

Membahas mengenai kendala selanjutnya, maka menurut beliau perlu memahami dulu apa yang menjadi pertimbangan utama atau dasar bagi Badan Pertanahan Nasional dalam lingkup penelitian ini Badan Pertanahan Nasional Kota Samarinda dalam menerbitkan sertifikat hak pakai tanah diatas tanah negara. Menurut beliau pertimbangan utama atau dasar tersebut dapat ditemukan pada perihal menimbang dalam ketentuan Peraturan Menteri Negeri Agraria/Kepala Badan Pertanahan Nasional Nomor 9 Tahun 1999 Tentang Tata Cara Pemberian Dan Pembatalan Hak Atas Tanah Negara Dan Hak Pengelolaan yang menyatakan bahwa pemberian sertifikat hak pakai tanah diatas tanah negara merupakan implementasi pemberian hak atas tanah sesuai dengan amanat Undang-undang Nomor 5 Tahun 1960 dan Peraturan Pemerintah Nomor 40 Tahun 1996 perlu diatur mengenai tata cara pemberian dan pembatalan hak atas Tanah Negara dan Hak Pengelolaan. Setelah memahami dasar pertimbangan diterbitkannya sertifikat hak pakai diatas tanah negara, maka lebih lanjut dalam wawancara beliau menyatakan bila ada sertifikat yang diterbitkan tentu sertifikat tersebut juga dapat berakhir, sehingga sertifikat hak pakai tanah yang digunakan oleh Pemerintah Daerah Kota Samarinda sebagai aset daerah tentu penggunaanya juga dapat berakhir.

Berakhirnya hak pakai tanah diatas tanah negara tersebut menurut beliau bukanlah tanpa alasan. Beliau menjelaskan bahwa ada beberapa faktor yang mempengaruhi berakhirnya hak pakai tanah diatas tanah negara diantaranya habisnya jangka waktu hak pakai dan adanya pembatalan sertifikat. Hal ini sesuai dengan ketentuan Peraturan Menteri Negeri Agraria/Kepala Badan Pertanahan Nasional Nomor 9 Tahun 1999 Tentang Tata Cara Pemberian Dan Pembatalan Hak Atas Tanah Negara Dan Hak Pengelolaan. Berakhirnya jangka waktu sertifikat hak pakai menurut beliau dapat diperpanjang kembali, dan dasar pertimbangan terkait perpanjangan jangka waktu sertifikat hak pakai tanah pada tanah negara bagi Badan Pertanahan Nasional Kota Samarinda ialah ketentuan Pasal 142 sampai dengan Pasal 149 Peraturan Menteri Negeri Agraria/Kepala Badan Pertanahan Nasional Nomor 9 Tahun 1999 Tentang Tata Cara Pemberian Dan Pembatalan Hak Atas Tanah Negara Dan Hak Pengelolaan. Berdasarkan penjelasan beliau tersebut, maka menurut analisa penulis bukan hanya tidak aktifnya pemohon mengajukan permohonan namun juga karena peran Badan Pertanahan Nasional dalam lingkup penelitian ini Badan Pertanahan Nasional Kota Samarinda cenderung pasif menunggu adanya pemohon yang mengajukan pembatalan sertifikat hak pakai tanah khususnya tanah negara. Hal ini diperkuat dengan adanya argument beliau yang menyatakan bahwa belum ada pembatalan sertifikat hak pakai tanah yang dilakukan diluar dari ketentuan peraturan perundangundangan yaitu Peraturan Menteri Negeri Agraria/Kepala Badan Pertanahan Nasional Nomor 9 Tahun 1999 Tentang Tata Cara Pemberian Dan Pembatalan Hak Atas Tanah Negara Dan Hak Pengelolaan.

Artinya, selama ini Badan Pertanahan Nasional dalam lingkup penelitian ini Badan Pertanahan Nasional Kota Samarinda hanya menunggu pemohon dalam mengajukan pemohonan untuk melaksanakan prosedur pembatalan sertifikat hak pakai tanah khususnya yang tercatat sebagai aset pemerintah dimana menurut beliau peran dari Badan Pertanahan Nasional termasuk Badan Pertanahan Nasional Kota Samarinda hanya sebagai pelaksana bukan sebagai eksekutor sehingga sifatnya pasif dan tidak atif dalam hal pembatalan sertifikat hak pakai diatas tanah negara. Menurut pengamatan penulis, hal itu sendiri terjadi karena Badan 
Pertanahan Nasional dalam lingkup penelitian ini Badan Pertanahan Nasional Kota Samarinda memiliki batasan wewenang bukan sebagai pengambil keputusan terkait penyelesaian prosedur pembatalan sertifikat hak pakai tanah diatas tanah negara, namun hanya sebagai pelaksana dari peraturan perundangundangan terkait urusan pertanahan, padahal menurut penulis Badan Pertanahan Nasional dalam lingkup penelitian ini Badan Pertanahan Nasional Kota Samarinda merupakan alat bagi penegakan hukum agraria nasional bukan hanya sebagai pelaksana hukum agraria nasional namun juga seharusnya dapat menjadi eksekutor (pengambil keputusan), sehingga dirasa kurang dalam melaksanakan fungsi dan tugas Badan Pertanahan Nasional dalam lingkup penelitian ini Badan Pertanahan Nasional Kota Samarinda sebagai penegak hukum agraria nasional khususnya di Kota Samarinda.

Menurut penulis dengan diperluasnya peran Badan Pertanahan Nasional dalam lingkup penelitian ini Badan Pertanahan Nasional Kota Samarinda, maka apabila ada pelanggaran-pelanggaran yang ditemukan terkait sertifikat hak pakai tanah khususnya tanah negara yang telah tercatat sebagai aset pemerintah, Badan Pertanahan Nasional khususnya Badan Pertanahan Nasional Kota Samarinda dapat segera mengambil tindakan tegas dengan membuat keputusan untuk membatalkan sertifikat hak pakai tanah sesuai dengan peraturan perundang-undangan yang berlaku, tanpa harus menunggu adanya permohonan. Berdasarkan penjelasan tersebut dapat penulis simpulkan bahwa secara garis besar kendala yang dihadapi oleh Badan Pertanahan Nasional khususnya Badan Pertanahan Nasional Kota Samarinda dalam proses pembatalan sertifikat hak pakai tanah pada tanah negara sebagai aset Pemerintah Kota Samarinda didominasi oleh tidak aktifnya pemohon dalam mengajukan permohonan pembatalan hak atas tanah yang didukung oleh peran Badan Pertanahan Nasional khususnya Badan Pertanahan Nasional Kota Samarinda yang pasif dalam menyelesaikan permasalahan terkait proses pembatalan sertifikat hak pakai tanah pada tanah negara sebagai aset Pemerintah Kota Samarinda. Oleh karenanya, penulis berharap Badan Pertanahan Nasional khususnya Badan Pertanahan Nasional Kota Samarinda dapat aktif turut serta dalam mengantisipasi kendala tersebut, terkait prosedur pembatalan sertifikat pinjam pakai tanah pada tanah negara yang telah menjadi aset pemerintah.

\section{PENUTUP \\ KESIMPULAN DAN SARAN}

Pembatalan sertifikat hak pakai tanah pada tanah negara sebagai aset pemerintah disebabkan karena dua hal yaitu cacat administratif dan putusan pengadilan yang persyaratannya telah diatur dalam Peraturan Menteri Negeri Agraria/Kepala Badan Pertanahan Nasional Nomor 9 Tahun 1999 Tentang Tata Cara Pemberian Dan Pembatalan Hak Atas Tanah Negara Dan Hak Pengelolaan. Selain itu mengenai status tanah akibat adanya pembatalan sertifikat hak pakai tanah yang merupakan aset pemerintah kembali menjadi tanah negara, dan dilakukan tanpa menunggu proses penghapusan aset atau aktiva tetap dari Pemerintah Daerah, kemudian diberikan bentuk Surat Keputusan Pemabatalan Hak Atas Tanah yang dikeluarkan oleh Kepala Badan Pertanahan Nasional.

Kendala yang dihadapi oleh Badan Pertanahan Nasional Kota Samarinda dalam proses pembatalan sertifikat hak pakai tanah pada tanah negara sebagai aset Pemerintah Kota Samarinda didominasi oleh tidak aktifnya pemohon dalam mengajukan permohonan pembatalan hak atas tanah yang didukung oleh peran Badan Pertanahan Nasional Kota Samarinda yang pasif dalam menyelesaikan proses pembatalan sertifikat hak pakai tanah pada tanah negara sebagai aset Pemerintah Kota Samarinda.

Adapun saran dalam peneltian ini Penulis berharap kedepannya peran Badan Pertanahan Nasional khususnya Badan Pertanahan Nasional Kota Samarinda diperluas bukan sebagai pelaksana 
keputusan namun juga dapat sebagai pengambil keputusan, mengingat Badan Pertanahan Nasional khususnya Badan Pertanahan Nasional Kota Samarinda merupakan satu-satunya alat bagi penegakan hukum agraria nasional. Dan Penulis berharap kedepannya Badan Pertanahan Nasional khususnya Badan Pertanahan Nasional Kota Samarinda dapat aktif turut serta dalam mengantisipasi kendala tersebut, terkait prosedur pembatalan sertifikat pinjam pakai tanah pada tanah negara yang telah menjadi aset pemerintah.

\section{DAFTAR PUSTAKA}

\section{BUKU - BUKU}

Achmad Chulaemi, 1993, Hukum Agraria, Perkembangan, Macam Hak Atas Tanah dan Pemindahannya, Semarang, FH Undip.

Ali Achmad Chomzah, 2002, Hukum Pertanahan ; Pemberian Hak Atas Tanah Negara, Sertipikat dan Permasalahannya, Jakarta, Prestasi Pustaka.

Amiruddin, 2006, Pengantar Metode Penelitian Hukum. Jakarta, PT Raja Grafindo Persada.

Bachtiar Effendie. 1993. Pendaftaran Tanah di Indonesia dan Peraturanperaturan Pelaksanaannya. Cet.2. Bandung, Alumni.

Bahder Johan Nasution, 2008, Metode Penelitian Ilmu Hukum, Bandung, CV Mandar Maju.

Boedi Harsono, 2002. Hukum Agraria Indonesia, Himpunan Peraturanperaturan Hukum Tanah, Jakarta, Djambatan.

John Salindeho, 1993, Masalah Tanah Dalam Perkembangan, Jakarta, Sinar Grafika.

K. Wantijk Saleh, 1982, Hak Anda Atas Tanah, Jakarta, Ghalia Indonesia

Lexy J. Moleong, 2010, Metodelogi Penelitian Kualitatif, Ed. Rev, Jakarta, Remaja Rosdakarya
Maria S.W. Soemardjono, 2006. Kebijakan Pertanahan : Antara Regulasi dan Implementasi. Jakarta, Kompas.

Muhammad Bakri, 2007, Hak Menguasai Tanah Oleh Negara, Yogyakarta, Citra Media

Sudarto, 2002., Metodologi Penelitian Filsafat, Jakarta, Raja Grafindo Persada.

Sudjito,1987, Prona Pensertifikatan Tanah Secara Massal dan Penyelesaian Sengketa Tanah yang bersifat Strategis, Yogyakarta, Liberty

Urip Santoso. 2010. Pendaftaran dan Peralihan Hak atas Tanah. Jakarta, Kencana.

Waluyo Bambang, 2002, Penelitian Hukum Dalam Praktek, Jakarta, Sinar Grafika.

Peraturan Perundang - Undangan

Undang - Undang Dasar (UUD) 1945 Amandemen IV

Undang-Undang Nomor 5 Tahun 1960 tentang Undang-Undang Pokok Agraria

Peraturan Menteri Negara Agraria/Kepala Badan Pertanahan Nasional Nomor 9 tahun 1999 tentang Tata Cara Pemberian Dan Pembatalan Hak Atas Tanah Negara Dan Hak Pengelolaan

Peraturan Pemerintah Nomor 40 Tahun 1996 tentang Hak Guna Usaha, 
Hak Guna Bangunan Dan Hak

Pakai Atas Tanah

Peraturan Menteri Negara Agraria dan Tata

Ruang/ Kepala Badan Pertanahan

Nasional Republik Indonesia

Nomor 11 tahun 20116 tentang

Penyelesaian Kasus Pertanahan

Keputusan Menteri Negara Agraria/ Kepala

Badan Pertanahan Nasional Nomor

6 Tahun 1998 Tentang Pemberian
Hak Milik Atas Tanah Untuk

Rumah Tinggal 